\title{
Physiological and Biochemical Characterisation of Grape Rootstocks
}

\author{
J. Satisha*, S.D. Ramteke and G.S. Karibasappa
}

National Research Centre for Grapes, P.B. No. 3, Manjri Farm, Solapur Road, Pune - 412 307, Maharashtra, India

Submitted for publication: June 2007

Accepted for Publication: October 2007

Key words: grapes, rootstocks, characterisation, physiology, biochemistry, proteins, proline, phenolics

\begin{abstract}
Ten grape rootstocks were characterised for their various morphological, physiological and biochemical parameters. Significant differences were observed for most of the parameters studied. Rootstocks in the group of Vitis berlandierii $\times$ Vitis rupestris, such as 110 R, 1103 P, 99 R and B2-56, had a significantly higher content of total phenols, flavon-3ols, flaveonoids, proline and total protein. Optimum $\mathrm{C} / \mathrm{N}$ ratios in the mother vines of these rootstocks helped attain better rooting percentages of hardwood cuttings. Rootstocks such as Dog Ridge, 110 R, B2-56 and Salt Creek recorded the highest relative water content (RWC) and water-use efficiency (WUE) at single-leaf level, which is an important mechanism in overcoming drought tolerance. The high phenolic content in rootstocks such as Dog Ridge, $99 \mathrm{R}, 110 \mathrm{R}$ and $1103 \mathrm{P}$ may help in reducing the incidence of major grape diseases in commercial table varieties if grafted onto these rootstocks. This was established in our earlier studies of the incidence of powdery mildew in Thompson Seedless grafted onto different rootstocks. A significant and positive correlation was observed for WUE and total protein and proline content. Thus, the physio-biochemical characterisation of rootstocks may help to identify particular rootstocks that could influence a desired trait in commercial table / wine grape varieties after grafting.
\end{abstract}

\section{INTRODUCTION}

Grapes (Vitis vinifera L.) are one of the important fruit crops grown in the world and are cultivated widely in temperate and subtropical climates. Even though their origin was in temperate regions, they perform equally well in a tropical climate in India, where they are grown as an evergreen vine without undergoing dormancy. Hence, pruning practices are altered accordingly in central and peninsular India. Rootstocks are used in most grapegrowing countries to overcome biotic stresses like nematodes, phylloxera, root lice, etc. In India, however, rootstocks are gaining popularity because of their tolerance to abiotic stresses like drought and salinity. Under Indian conditions, Thompson Seedless is the most popular commercial variety and is grown in larger areas. But this variety is highly susceptible to major diseases, like downy mildew, powdery mildew and anthracnose. Extensive grafting experimentation has revealed that rootstocks exert their influence on several aspects of scion physiology (Rosa et al., 2003). Because of a different affinity of rootstocks for the scions, the right choice of appropriate rootstock is of great importance for the quality of grafted grapevines. Ampelography and ampelometry based on morphological differences between the varieties are known methods for varietal identification. A lot of molecular markers have been employed to characterise grape varieties and rootstocks (Dzhambazova et al., 2007). As the physiology and biochemistry of rootstocks vary under similar sets of management practices, the physiology and biochemical composition of the mother vines play an important role in the propagation, growth and development of the vine, water-use efficiency, pest and disease tolerance, quality of the grapes, etc. As grape rootstocks belong to different Vitis species, such as $V$. champinii, $V$. rupestris, $V$. berlandierii, $V$. longii, $V$. parviflora, etc., each rootstock has its own inherent capacity to synthesise biochemical constituents, which influence scion physiology, either directly or indirectly, after grafting (Satisha and Prakash, 2006). Some may influence drought tolerance through the accumulation of osmolytes, increasing water-use efficiency, while some may influence disease and pest resistance through the accumulation of polyphenols, phytoalexins, etc. Hence, it is necessary to categorise the rootstocks on the basis of various biochemical and physiological parameters so that it will be easier to recommend a rootstock for a specific purpose. Consequently, ten rootstocks were selected from the germplasm collection of the National Research Centre for Grapes, Pune to characterise them on the basis of their physiological and biochemical parameters.

\section{MATERIALS AND METHODS}

The rootstocks used for characterisation, which are available in the germplasm collection of the National Research Centre for Grapes, Pune, are represented in the Table 1.

This study was carried out in the experimental vineyard of the National Research Centre for Grapes, Pune in 2005 and 2006. Pune is situated in Midwest Maharashtra State (India) at an altitude of $559 \mathrm{~m}$ above mean sea level. It lies on $18.32^{\circ} \mathrm{N}$ latitude and $73.51^{\circ} \mathrm{E}$ longitude. Ten rootstocks, namely Dog Ridge, Salt Creek, V. champinii, Degrasette, 110 R, 1103 P, 99 R, B2-56, Teleki $5 \mathrm{~A}$ and $V$. longii, were selected in the rootstock mother vine blocks. The mother vines were five to six years old.

For the physiological and biochemical characterisation studies, fully developed and recently matured leaves were selected from the current season's growth (usually the fifth and sixth leaf from the apex). For studying the rooting success of the rootstocks, well-matured shoots were selected on the mother vines and cuttings with about three to four buds were prepared. The cuttings were subjected to a cold-water treatment for 24 hours to leach out the inhibitors present, and then dipped in IBA at $1000 \mathrm{ppm}$ for 30 to 60 seconds, before being planted in polythene bags filled with a 
potting mixture of red earth, sand and compost in a ratio of $2: 1: 1$. The success percentage was recorded 75 days after planting.

\section{Estimation of biochemical constituents}

\section{Sampling method}

The leaf samples were collected randomly from five mother vines of each rootstock. The samples were washed thoroughly with distilled water, air-dried and stored at $-20^{\circ} \mathrm{C}$. Each sample was subsequently lyophilised using a freeze drier (Benchtop $4 \mathrm{~K}$ VIRTIS) at $-78^{\circ} \mathrm{C}$. The lyophilised samples were blended thoroughly and sieved through a sieve with a mesh size of 40 and stored at $-20^{\circ} \mathrm{C}$ until further processing.

\section{Extraction of samples}

One gram of each of the different samples lyophilised in three replications each were extracted by overnight shaking at room temperature (RT) on a mechanical shaker in the dark. The solvent used was $80 \%$ aqueous methanol, as this has been reported to be a better solvent for polyphenol extraction (Bonilla et al., 2003). The mixture was centrifuged at $12000 \mathrm{rpm}$ for 15 minutes at $4^{\circ} \mathrm{C}$. The residues were re-extracted (three times, three hours each) under similar conditions. The completeness of the extraction for leaves was ensured by a qualitative Folin Ciocalteu negative test on Whattman filter paper No. 1. The filtrates were pooled and concentrated to one-third their volume using Turbovap concentrator under a gentle stream of nitrogen. The sample extracts

\section{TABLE 1}

Rootstocks and their parentage selected for the study.

\begin{tabular}{ll}
\hline Rootstock & Parentage or species \\
\hline Vitis Champinii clone & Vitis champinii \\
B2-56 (An accession at NRC Grapes, Pune) & Berlandierii $\times$ Rupestris \\
Degrasette & Vitis champinii \\
Dog ridge & Vitis champinii \\
110 R & Berlandierii $\times$ Rupestris \\
99 R & Berlandierii $\times$ Rupestris \\
1103 P & Berlandierii $\times$ Rupestris \\
Teleki 5A & Berlandierii $\times$ Riparia \\
St. George & Vitis rupestris \\
Salt Creek & Vitis champinii \\
\hline
\end{tabular}

were treated with chloroform to remove chlorophyll, and residual aqueous extracts were washed away with ethyl acetate (Park and Cha, 2003). The extracts were filtered through $0.45 \mathrm{Mm}$ filters and stored at $0^{\circ} \mathrm{C}$ until further analysis (Ju and Howard, 2003).

\section{Total phenolic content}

The total polyphenol content of the extract was determined using the Folin-Ciocalteu method (Singleton and Rossi, 1965), using gallic acid as the standard. The concentration of the total phenolics was expressed as the gallic acid equivalent (GAE mg. $\mathrm{g}^{-1}$ ) of the lyophilised sample.

\section{Total flavonoids}

Total flavonoids were determined colorimetrically following the procedures derived by Kim et al. (2003). The amount of total flavonoids was expressed as the catechin equivalent $\left(\mathrm{CE}, \mathrm{mg} \cdot \mathrm{g}^{-1}\right)$ of the lyophilised sample.

\section{Flavon-3-ols}

The total flavon-3-ol content was estimated using the DMACA method (Arnous et al., 2001). The concentration of total flavon3-ols was expressed as the CE ( $\mathrm{mg}^{-\mathrm{g}^{-1}}$ ) of the lyophilised sample.

\section{Total flavonols}

The flavonol content was estimated by measuring the absorbance of the extract at $360 \mathrm{~nm}$ after the addition of $2 \% \mathrm{HCl}$ (Mazza et al., 1999) and expressed as the quercitin equivalent (QE mg.g $\mathrm{g}^{-1}$ ) of the lyophilised sample.

Reducing sugar was estimated by the dinitro salicylic acid (DNSA) method, proline was estimated by the sulphosalicylic acid method, total proteins were estimated using Lowry's method, while carbohydrate and nitrogen were estimated by the anthrone method and the microkjeldhal method respectively. The carbohydrate/nitrogen ratio $(\mathrm{C} / \mathrm{N}$ ratio) was derived using the respective values of carbohydrates and nitrogen. Leaf area was estimated using a leaf area meter (Model, Licor) and the values were expressed in $\mathrm{cm}^{2}$.

\section{Observations of gas exchange parameters}

Gas exchange parameters such as photosynthetic rate and transpiration rate were measured using an infrared gas analyser (Model, Licor) in the leaves before they were sampled for the estimation of the various biochemical constituents. The readings were measured in full sunlight between 10:00 and 12:00. The area of the

TABLE 2

Biochemical constituents in the mother vines of grape rootstocks.

\begin{tabular}{|c|c|c|c|c|c|}
\hline Rootstocks & $\begin{array}{l}\text { Total phenols } \\
\text { (mg/g GAE) }\end{array}$ & $\begin{array}{c}\text { Flavon-3-ols } \\
\text { (mg/g CE) }\end{array}$ & $\begin{array}{l}\text { Flavonoids } \\
\text { (mg/g CE) }\end{array}$ & $\begin{array}{c}\text { Proline } \\
\text { (mg/g fresh wt) }\end{array}$ & $\begin{array}{l}\text { Proteins } \\
(\mathrm{mg} / \mathrm{g})\end{array}$ \\
\hline V. champinii & $14.95 \pm 3.71$ & $1.71 \pm 0.19 \mathrm{~d}$ & $25.52 \pm 3.95 \mathrm{c}$ & $5.21 \pm 0.83 a$ & $0.68 \pm 0.03 \mathrm{~cd}$ \\
\hline B2-56 & $21.96 \pm 4.62 \mathrm{~cd}$ & $2.29 \pm 0.12 \mathrm{c}$ & $22.91 \pm 1.55 \mathrm{~d}$ & $5.16 \pm 0.39 b$ & $0.86 \pm 0.10 b$ \\
\hline Degrasette & $17.30 \pm 2.48$ & $0.41 \pm 0.05 f$ & $25.55 \pm 3.12 \mathrm{c}$ & $5.27 \pm 0.39 \mathrm{a}$ & $0.74 \pm 0.08 \mathrm{c}$ \\
\hline Dog Ridge & $29.91 \pm 2.78 b$ & $1.67 \pm 0.20 \mathrm{~d}$ & $28.16 \pm 5.51 b$ & $4.95 \pm 0.37 c$ & $0.94 \pm 0.07 b$ \\
\hline $110 \mathrm{R}$ & $28.04 \pm 1.89 b$ & $2.90 \pm 0.38 \mathrm{a}$ & $30.54 \pm 2.64 \mathrm{a}$ & $5.42 \pm 0.56 \mathrm{a}$ & $1.13 \pm 0.10 \mathrm{a}$ \\
\hline $99 \mathrm{R}$ & $33.33 \pm 1.56 \mathrm{a}$ & $2.51 \pm 0.22 b$ & $22.92 \pm 0.16 \mathrm{~cd}$ & $5.25 \pm 0.41 \mathrm{a}$ & $1.10 \pm 0.03 a$ \\
\hline $1103 \mathrm{P}$ & $29.60 \pm 2.13 b$ & $2.19 \pm 0.08 \mathrm{c}$ & $24.75 \pm 2.04 c$ & $5.09 \pm 0.09 b$ & $1.04 \pm 0.16 \mathrm{ab}$ \\
\hline Teleki 5A & $23.33 \pm 5.79 c$ & $1.00 \pm 0.09 \mathrm{e}$ & $22.46 \pm 1.27 \mathrm{~d}$ & $4.07 \pm 0.23 \mathrm{~d}$ & $0.60 \pm 0.05 \mathrm{~d}$ \\
\hline St. George & $14.71 \pm 0.16 \mathrm{e}$ & $1.37 \pm 0.20 \mathrm{de}$ & $20.82 \pm 2.47 \mathrm{e}$ & $5.00 \pm 0.88 b$ & $0.58 \pm 0.04 d$ \\
\hline Salt Creek & $20.26 \pm 1.86 d$ & $2.37 \pm 0.39 b c$ & $32.62 \pm 2.87 \mathrm{a}$ & $4.04 \pm 0.45 \mathrm{~d}$ & $0.79 \pm 0.03 \mathrm{c}$ \\
\hline
\end{tabular}

$*$ The values are mean \pm SD of three replications, and those marked with different letters of the alphabet in the same column are significantly different at $\mathrm{P} \leq 0.05$. 
chamber for holding the leaves was $6.25 \mathrm{~cm}^{2}$. The photosynthetic rate was expressed as $\mu \mathrm{mol} \mathrm{CO}_{2} / \mathrm{m}^{2} / \mathrm{sec}$, while the transpiration rate was expressed as $\mathrm{mmol} \mathrm{H}_{2} \mathrm{O} / \mathrm{m}^{2} / \mathrm{sec}$. Water-use efficiency at the level of a single leaf was derived using the formula WUE = photosynthetic rate / transpiration rate.

\section{Statistics}

The results were analysed by means of the Student's unpaired ttest using the SPSS statistical package version 11.0, and a $\mathrm{p}$ value of 0.05 was taken to be significant.

\section{RESULTS AND DISCUSSION}

\section{Biochemical parameters}

The various biochemical constituents that were analysed in the leaves of the different rootstocks are presented in Table 2. Among the rootstocks, total phenol content was highest in $99 \mathrm{R}$, followed by 1103 P, Dog Ridge, 110 R and Teleki 5A. The lowest phenolic content was in St. George and $V$. champinii. Similarly, the content of flavon-3-ols and flavonoids was maximum in $110 \mathrm{R}, 99 \mathrm{R}$ and 1103 P, followed by Salt Creek, B2-56 and Dog Ridge, and its was the least in Degrasette. The maximum proline content was found in $110 \mathrm{R}, 99 \mathrm{R}, 1103 \mathrm{P}$ and Degrasette, followed by V. champinii, St. George and Dog Ridge, and the least proline was recorded in Teleki 5A. The highest protein content was recorded in $110 \mathrm{R}$, $1103 \mathrm{P}$ and $99 \mathrm{R}$.

Several workers believe that the characterisation of germplasm based on biochemical composition is useful in identifying synonyms and also helps in identifying the potential accessions for a given trait. Asensio et al. (2002) characterised nine white grape cultivars grown in the Extremadura region of Spain at various phenological stages and characterised the amino acid composition in the must at maturity. They concluded that the two methods were complementary and able to differentiate varieties. They could also identify commonalities among and similarities between the cultivars. It was found that berry protein could be used as a biochemical marker to identify genetic variation in Muscadine cultivars. SDS-PAGE resolved the berry protein content into 13 distinct polypeptides, ranging in molecular weight from 10 to $100 \mathrm{KDa}$. One of the bands of $30 \mathrm{KDa}$ was found to be cultivar specific, being present in some and absent in others (Mazhan et al., 2002). In the present study we could see this trend, where accessions belonging to the same group, such as $110 \mathrm{R}, 1103 \mathrm{P}$, $99 \mathrm{R}$ and B2-56, had a similar biochemical composition to those belonging to other Vitis species. Rootstocks accordingly may be grouped into various categories, like high phenol accumulators, high carbohydrate and high sugar accumulators, and thereby it is possible to standardise the propagation practices for a particular rootstock to obtain better rooting percentages.

In sugarcane, Almeida and Crocomo (1994) could determine isozyme profiles of the enzymes esterase and peroxidase, and the levels of total soluble protein and soluble solids (sucrose) of several cultivars. Esterase isozyme showed a specific electrophoresis pattern for each of the cultivars, while the peroxidase made it possible to arrange the cultivars into groups, each with a specific electrophoretic pattern. The isozymes of both esterase and peroxidase were constant in a given cultivar, although soluble protein and soluble sugars varied among the cultivars. These authors therefore suggested that biochemical parameters are useful for the characterisation of cultivars.

The species of the genus Vitis that have a larger content of polyphenols ( $V$. rotundifolia) are more resistant to infection caused by powdery mildew and, when infected, produce larger amounts of polyphenols than varieties that are more susceptible (Dai et al., 1994). Dai et al. (1994) also classified the grape specie $V$. vinifera as susceptible, $V$. rupestris as intermediate and $V$. rotundifolia as resistant. The resistant variety showed an enriched content of gallic acid derivatives and catechin tannins compared to the sensitive variety. This is in agreement with the present study, which found that rootstocks belonging to $V$. berlandierii $\times$ V. rupestris (110 R, 99 R, 1103, B2-56) could accumulate more phenolic compounds and their derivatives. In our earlier studies on the effect of rootstocks on the incidence of powdery mildew in field-grafted Thomson Seedless grapes, we recorded a lesser incidence of powdery mildew on bunches in Thompson Seedless grafted on $110 \mathrm{R}$ rootstock, followed by those grafted on $1103 \mathrm{P}$, $99 \mathrm{R}$ and Dog Ridge rootstocks. There was a negative correlation between total phenolic content and the incidence of powdery mildew (unpublished data).

Though the present study has not covered the influence of the effect of rootstocks on the physiology and biochemistry of scions after grafting or budding, the inherent capacity of the rootstocks

\section{TABLE 3}

Factors influencing rooting success in mother vines of grapes.

\begin{tabular}{|c|c|c|c|c|c|c|}
\hline Rootstock & $\begin{array}{c}\text { Carbohydrate } \\
(\mathrm{mg} / \mathrm{g})\end{array}$ & $\begin{array}{l}\text { Nitrogen } \\
(\%)\end{array}$ & $\mathrm{C} / \mathrm{N}$ ratio & $\begin{array}{l}\text { Reducing sugar } \\
(\mathrm{mg} / \mathrm{g})\end{array}$ & $\begin{array}{l}\text { Leaf area } \\
\quad\left(\mathrm{cm}^{2}\right)\end{array}$ & $\begin{array}{l}\text { Success } \\
(\%)\end{array}$ \\
\hline V. champinii & $50.44 \pm 1.04 \mathrm{a}$ & $0.52 \pm 0.03 \mathrm{bc}$ & $9.70 \pm 0.81 \mathrm{a}$ & $22.55 \pm 1.17 \mathrm{e}$ & $33.16 \pm 2.17 \mathrm{a}$ & $52.00 \pm 2.00 \mathrm{e}$ \\
\hline B2-56 & $45.30 \pm 2.66 \mathrm{~b}$ & $0.50 \pm 0.04 \mathrm{c}$ & $8.05 \pm 1.03 c$ & $31.66 \pm 0.79 \mathrm{ab}$ & $12.86 \pm 2.59 \mathrm{e}$ & $68.66 \pm 2.60 c$ \\
\hline Degrasette & $48.66 \pm 1.35 \mathrm{ab}$ & $0.51 \pm 0.03 \mathrm{c}$ & $9.49 \pm 0.88 \mathrm{a}$ & $23.70 \pm 2.23 \mathrm{de}$ & $15.11 \pm 1.52 \mathrm{~d}$ & $45.33 \pm 8.08 f$ \\
\hline Dog Ridge & $47.16 \pm 2.76 b$ & $0.50 \pm 0.01 \mathrm{c}$ & $8.37 \pm 0.58 c$ & $25.30 \pm 4.24 \mathrm{c}$ & $13.39 \pm 3.62 \mathrm{de}$ & $68.66 \pm 2.30 \mathrm{c}$ \\
\hline $110 \mathrm{R}$ & $43.00 \pm 2.58 \mathrm{bc}$ & $0.49 \pm 0.02 \mathrm{~cd}$ & $8.71 \pm 0.16 b$ & $22.29 \pm 1.98 \mathrm{e}$ & $15.41 \pm 0.99 \mathrm{~d}$ & $70.33 \pm 1.15 b c$ \\
\hline $99 \mathrm{R}$ & $47.43 \pm 2.58 b$ & $0.68 \pm 0.09 \mathrm{a}$ & $8.05 \pm 1.24 \mathrm{c}$ & $28.55 \pm 1.74 b$ & $18.23 \pm 2.41 \mathrm{c}$ & $78.00 \pm 2.32 \mathrm{a}$ \\
\hline $1103 \mathrm{P}$ & $41.23 \pm 1.25 \mathrm{c}$ & $0.52 \pm 0.06 \mathrm{bc}$ & $8.0 \pm 0.90 \mathrm{~cd}$ & $25.26 \pm 7.42 \mathrm{~cd}$ & $16.71 \pm 1.05 \mathrm{~cd}$ & $77.33 \pm 3.05 \mathrm{a}$ \\
\hline Teleki 5A & $45.03 \pm 1.15 b$ & $0.58 \pm 0.04 b$ & $7.74 \pm 0.61 \mathrm{~d}$ & $34.45 \pm 1.64 \mathrm{a}$ & $33.91 \pm 1.37 \mathrm{a}$ & $50.66 \pm 3.05 \mathrm{e}$ \\
\hline St. George & $50.00 \pm 1.31 \mathrm{a}$ & $0.43 \pm 0.03 \mathrm{~d}$ & $8.4 \pm 1.10 \mathrm{bc}$ & $25.64 \pm 1.10 \mathrm{c}$ & $32.07 \pm 2.11 \mathrm{a}$ & $67.33 \pm 5.03 \mathrm{~cd}$ \\
\hline Salt Creek & $43.53 \pm 1.52 b c$ & $0.62 \pm 0.03 a$ & $7.00 \pm 0.59 \mathrm{e}$ & $25.57 \pm 4.34 c$ & $22.36 \pm 0.95 b$ & $65.33 \pm 4.61 d$ \\
\hline
\end{tabular}

* The values are mean $\pm \mathrm{SD}$ of three replications, and those marked with different letters of the alphabet in the same column are significantly different at $\mathrm{P} \leq 0.05$. 
will still have a positive influence on these aspects after grafting. Several reports are available on the effect of rootstocks on the biochemical composition of the scion in various species, such as apple (Brown et al., 1985), soybean (Carver et al., 1987), etc. In Hevea, it has been found that rootstocks have a profound influence on the biochemical composition of the leaves, especially in terms of enzymes, reducing sugars, phenols and amino acids (Sobhana, 1998). Most of the biochemical constituents, such as the various enzymes, plant hormones, proteins and amino acids, as well as phenolic compounds, are synthesised in the plant system with the help of various micronutrients as cofactors in their synthesis. The efficient uptake of these nutrients from the soil solution varies with the rootstocks because of their preference for certain nutritional elements. Thus, the characterisation of rootstocks may also help in identifying efficient rootstocks that may either synthesise more stress hormones to cope with drought and salt stress, synthesise more phenolic compounds to resist attacks of diseases, or synthesise specific proteins in response to various stresses, or which also indirectly influence various other physiological developments, etc.

Several enzymes, such as aspartate, aminotransferase, leucine, aminopeptidase, alkaline phosphatase and phosphogluco-isomerase, showed polymorphism in the scion tissues collected from trees grafted on different rootstocks of Hevea species (Krishnakumar et al., 1992). Rootstocks have been found to influence the isozyme pattern of peroxidase, esterase and catalase in bud grafts of five Hevea clones (Sobhana et al., 2000). There is a recent report on the long-distance movement of mRNA from the stock to the scion in tomato grafts (Kim et al., 2001). The translocated mRNA caused morphological changes in the scion leaves similar to the morphology of the stock leaves, suggesting that the translocated mRNA was functional. It is also interesting to note that a lowcapsaicin variety of red bell pepper grafted onto a high-capsaicin rootstock gradually produced red peppers that were very hot, and this was inherited by the next generation, as in the case of genetic transformation (Ohta and Chuong, 1975; Hirata et al., 1986). This indicates that there is a genetic basis for stock-scion interaction and at least one effect of rootstock reported in the literature has been genetically stable and heritable.

In the present study, the concentration of the amino acid proline was maximum in the rootstocks belonging to the $V$. berlandierii and $V$. rupestris groups, while it was moderate in Dog Ridge and Salt Creek rootstocks and least in Teleki 5A, which are from different Vitis species. Proline is one of the important osmoprotectants during drought and salinity stress and the rootstocks can be categorised on the basis of proline synthesis and its accumulation in the leaves. The concentrations of eight amino acids, total free amino acids, total nitrogen and nitrogen in the free amino acid fraction in the juices of 28 table grape varieties was determined at both an early and late stage of maturity. Arginine, proline, glutamic acid and alanine were the most predominant amino acids. The varieties were classified into four groups according to which of these acids predominated (Kliewer, 1969).

As grapes are propagated vegetatively by hardwood cuttings, the success of rooting depends on various biochemical constituents of the mother vines, such as the $\mathrm{C} / \mathrm{N}$ ratio, reducing sugars, total phenols, etc. The maximum $\mathrm{C} / \mathrm{N}$ ratio was recorded in Degrasette and $V$. champinii, while moderate $\mathrm{C} / \mathrm{N}$ ratios were recorded in Dog Ridge, 110 R, 1103 P, 99 R and St. George. The lowest C/N ratio was recorded in Teleki $5 \mathrm{~A}$ and Salt Creek. The reducing sugar content was highest in Teleki 5A, B2-56 and 99 R, and moderate reducing sugar was recorded in St. George, Salt Creek, Dog Ridge, $1103 \mathrm{P}$ and $110 \mathrm{R}$. The lowest reducing sugar was found in Degrasette and $V$. champinii. Rooting success was maximum in 99 R, 1103 P and 110 R, followed by Dog Ridge, St. George, Salt Creek and B2-56. The least success was recorded in Degrasette, V. champinii and Teleki 5A (Table 3).

The rooting ability of hardwood and softwood cuttings of V. kiusiana Momiyama, a Japanese wild type which is very difficult to root even with IBA treatment, was investigated on the basis of their biochemical composition. Ethanol extracts from dormant shoots of both $V$. kiusiana and Muscat of Alexandria inhibited the root growth of rice seedlings, but the $V$. kiusiana extract displayed strong inhibition. These solutions seemed to contain phenolic compounds, but when PVPP, a phenolic absorbent was added, it improved the root growth of rice seedlings. The seasonal endogenous phenolic compound content per dry weight of $V$. kiusiana shoots exceeded that of Campbell Early. The results show that the rooting ability of $V$. kiusiana cuttings is very poor because of excess endogenous phenolics in the shoot (Mochioka et al., 2002). In the present study, although the rootstocks such as 1103 P, 99

\section{TABLE 4}

Gas exchange parameters in the mother vines of grape rootstocks.

\begin{tabular}{|c|c|c|c|c|}
\hline Rootstocks & $\begin{array}{c}\text { Ps } \\
\left(\mu \mathrm{mol} / \mathrm{cm}^{2} / \mathrm{sec}\right)\end{array}$ & $\begin{array}{l}\text { Transpiration } \\
\left(\mathrm{mmol} / \mathrm{cm}^{2} / \mathrm{sec}\right)\end{array}$ & $\begin{array}{c}\text { WUE } \\
(\mu \mathrm{mol} / \mathrm{mmol})\end{array}$ & $\begin{array}{c}\text { RWC } \\
(\%)\end{array}$ \\
\hline V. champinii & $7.70 \pm 0.50 \mathrm{c}$ & $6.29 \pm 0.28 \mathrm{a}$ & $1.21 \pm 0.11 \mathrm{~d}$ & $71.93 \pm 4.05 \mathrm{e}$ \\
\hline B2-56 & $7.42 \pm 0.65 \mathrm{~cd}$ & $6.10 \pm 0.78 \mathrm{a}$ & $1.31 \pm 0.05 \mathrm{c}$ & $81.17 \pm 9.19 b$ \\
\hline Degrasette & $7.82 \pm 0.73 \mathrm{c}$ & $5.87 \pm 1.17 \mathrm{~b}$ & $1.25 \pm 0.11 \mathrm{c}$ & $61.31 \pm 8.52 \mathrm{f}$ \\
\hline Dog Ridge & $8.36 \pm 0.69 b$ & $5.79 \pm 0.37 b c$ & $1.44 \pm 0.20 \mathrm{~b}$ & $83.57 \pm 2.97 \mathrm{ab}$ \\
\hline $110 \mathrm{R}$ & $8.83 \pm 0.32 \mathrm{a}$ & $5.62 \pm 0.35 \mathrm{c}$ & $1.57 \pm 0.11 \mathrm{a}$ & $84.56 \pm 4.36 a$ \\
\hline $99 \mathrm{R}$ & $8.55 \pm 8.07 \mathrm{a}$ & $5.94 \pm 0.21 b$ & $1.43 \pm 0.19 b$ & $75.72 \pm 3.20 \mathrm{~cd}$ \\
\hline $1103 \mathrm{P}$ & $8.97 \pm 0.26 \mathrm{a}$ & $6.10 \pm 0.52 \mathrm{ab}$ & $1.47 \pm 0.09 \mathrm{~b}$ & $76.96 \pm 1.62 \mathrm{c}$ \\
\hline Teleki 5A & $7.01 \pm 0.15 \mathrm{e}$ & $5.72 \pm 0.45 \mathrm{c}$ & $1.22 \pm 0.12 \mathrm{~d}$ & $74.31 \pm 4.78 \mathrm{~d}$ \\
\hline St. George & $6.60 \pm 1.33 f$ & $5.13 \pm 0.88 \mathrm{~d}$ & $1.28 \pm 0.18 \mathrm{c}$ & $78.55 \pm 3.51 \mathrm{c}$ \\
\hline Salt Creek & $7.42 \pm 0.65 \mathrm{~cd}$ & $6.10 \pm 0.78 \mathrm{ab}$ & $1.21 \pm 0.05 \mathrm{~d}$ & $81.78 \pm 3.12 b$ \\
\hline
\end{tabular}

* The values are means $\pm \mathrm{SD}$ of three replications, and those marked with different letters of the alphabet in the same column are significantly different at $\mathrm{P} \leq 0.05$. 
TABLE 5

Correlation matrix of rooting success with various physio-biochemical parameters in rootstocks.

\begin{tabular}{|c|c|c|c|c|c|c|c|}
\hline & Success \% & Phenols & R. sugars & Proline & Protein & WUE & $\mathrm{C} / \mathrm{N}$ ratio \\
\hline Phenols & & 1.00 & 0.16 & 0.13 & $0.84 * *$ & $0.78 * *$ & -0.37 \\
\hline Proline & & & & 1.00 & 0.47 & $0.54^{*}$ & $0.69^{*}$ \\
\hline Protein & & & & & 1.00 & $0.88^{* *}$ & -0.13 \\
\hline WUE & & & & & & 1.00 & -0.17 \\
\hline
\end{tabular}

** Significant at $1 \%$

* Significant at $5 \%$

$\mathrm{R}$, Dog Ridge and $110 \mathrm{R}$ contained more phenolic compounds than the leaves of the mother vines, their optimum $\mathrm{C} / \mathrm{N}$ ratio must have contributed to their better rooting percentage. The variation in rooting percentage of different rootstocks may be a genetic factor. Some species of Vitis are difficult to root and some are easy to root. $V$. vinifera is easy to root, $V$. champinii and $V$. rupestris are fairly easy to root, while $V$. berlandierii and $V$. longii are difficult to root (Anonymous, 1992). The possible reason for the reduction in the rooting percentage of a few rootstocks may be due to a higher content of rooting inhibitors and lesser concentrations of auxins. In his study of the relationship between carbohydrates and nitrogen and the rooting of stem cuttings, Sturve (1981) reported that a high $\mathrm{C} / \mathrm{N}$ ratio in cutting tissues promoted rooting, but did not accurately predict the degree of rooting response. Sadhu and Bose (1982) reported that the levels of soluble sugar and the $\mathrm{C} / \mathrm{N}$ ratio correlated positively with rooting in guava. Spiegel (1954) used chromatography to suggest the presence of two inhibitors associated with the rooting response of grapes. Leaching the cutting with water enhanced the quality and quantity of roots. An inhibitor released into the water during leaching had a detrimental effect on the rooting of cuttings of the easily rooted $V$. vinifera. Shy-rooting cuttings of $V$. berlandierii seemed to possess high inhibitor content. Many of the workers who have thoroughly tested the $\mathrm{C} / \mathrm{N}$ ratio status of mother vines and rooting ability have stated that a $\mathrm{C} / \mathrm{N}$ ration that is too high or too low is not favourable for rooting success. This is evident from this study, which shows that rootstocks such as Degrasette and $V$. champinii have the highest $\mathrm{C} / \mathrm{N}$ ratio, while Teleki $5 \mathrm{~A}$ has the lowest $\mathrm{C} / \mathrm{N}$ ratio, and the corresponding percentage of the rooting success was the least when compared to other rootstocks that have a $\mathrm{C} / \mathrm{N}$ ratio in the moderate range.

\section{Gas exchange parameters}

Gas exchange parameters play an important role in determining the ability of plants to photosynthesise and utilise water efficiently at the level of a single leaf. This is one of the important drought tolerance mechanisms in most crop species. The gas exchange parameters of different rootstocks are presented in the Table 4. The photosynthetic rate was highest in 110R, 1103 P, $99 \mathrm{R}$ and Dog Ridge, followed by Degrasette, Salt Creek, V. champinii and B2-56, and lowest in the Teleki 5A and St. George rootstocks. Similarly, the transpiration rate was lowest in 110 R, Dog Ridge, Teleki 5A and St. George, and least in V. champinii, 1103 P, Salt Creek and B2-56. The water-use efficiency at the single-leaf level was highest in 110R, 1103 P, Dog Ridge, 99 R and B2-56. The lowest WUE was recorded in $V$. champinii, Teleki 5A and Degrasette. The relative water content in the leaves follows the same trend as WUE in the rootstocks.

Twenty genotypes were screened, including rootstocks, table varieties and related species. A low transpiration rate was recorded in the cultivar Kishmish Chorneyi and in the rootstocks SO4, Teleki 5A, 1613 C, 1103 P and St. George. A high water potential was recorded in all genotypes, except $1613 \mathrm{C}$ and Concord. High proline accumulation was recorded in $V$. longii, Degrasette, Dog Ridge and Salt Creek (Ramteke and Karibasappa, 2005). In another study to test the effect of twelve rootstocks on Sultana grapes, Salt Creek was the highest yielding rootstock and Dog Ridge was the second highest. Vines on $V$. berlandierii hybrids, like $110 \mathrm{R}$ and 420-A, yielded less than own-rooted Sultana. Grapes on the two $V$. champinii rootstocks were more vigorous than the other vines. Vegetative growth was highest on Dog Ridge, followed by Salt Creek (Sauer, 1972). The variation in yield on the different rootstocks may be due to their nutrient uptake ability, their photosynthetic ability, etc. In the present study, it was observed that rootstocks like 110 R, 1103 P, 99 R and Dog Ridge had the highest photosynthetic rate and a reduced transpiration rate, thus increasing their water-use efficiency at the single-leaf level. Similar findings were reported in a study that evaluated rootstocks for Thompson Seedless grapes, where those grafted on $110 \mathrm{R}$ recorded a maximum yield per vine, followed by those on Dog Ridge, thus confirming the effect of rootstock on increasing the yield. The lowest yield was recorded on grapes grafted onto St. George, and in own-rooted vines (Anonymous, 2006).

A significant and positive correlation was observed between rooting percentage, total proteins and WUE, while a negative correlation was observed between success percentage and total phenols. Proline and WUE had a significantly positive correlation, while total protein and water-use efficiency correlated positively (Table 5). The role of phenols in rooting was studied by Nanda (1979), who reported a higher level of phenols as a possible cause for the reduction in rooting percentage. The same study revealed an inverse relationship between total phenols and rooting percentage. Proline, an amino acid, is one of the important osmoprotectants reported in several crops, and helps plants to overcome the adverse effects of drought and salinity stress. An increased accumulation of proline, abscissic acid (ABA), potassium, etc. was reported by Satisha et al. (2006), and this resulted in increased 
water-use efficiency in grape rootstocks under reduced soil moisture conditions. These authors also reported a strong positive correlation between WUE and the ABA content of grape rootstocks under moisture-stress conditions.

\section{CONCLUSION}

It is concluded from the present study that rootstocks vary in their expression of various biochemical and physiological parameters under a given set of environment conditions. The characterisation of grape rootstocks on the basis of physiological, morphological and biochemical parameters helps in identifying the rootstock that is suitable for a particular trait and, accordingly, it is possible to recommend rootstocks for given situations. In the present investigation, rootstocks in the group of $V$. berlandierii $\times V$. rupestris, such as 110 R, 99 R, 1103 P and B2-56, as well as Dog Ridge, recorded the highest values for total phenols, total proteins, flavonoids, flavon-3-ols and optimum $\mathrm{C} / \mathrm{N}$ ratio, which may help these rootstocks in overcoming the incidence of important grape diseases and lead to a better rooting percentage respectively. Apart from the biochemical and physiological parameters studied, several anatomical, physiological and biochemical parameters need to be studied for the further characterisation of rootstocks. Some of the important parameters that should be studied in the future include stomatal density, the presence of thick cuticles, carbon isotope discrimination, the accumulation of glycine betaine, ABA and cytokines, the characterisation of different stress proteins, and gene expression studies, which help in characterising the grape rootstocks and recommending various rootstocks for different situations based on soil and climatic conditions.

\section{LITERATURE CITED}

Almeida, M.D. \& Crocomo, O.J., 1994. Biochemical characterization of sugarcane cultivars: isozymes, soluble proteins and Brix value. Sci. Agric. 51, 422-429.

Anonymous, 1992. Rootstock manual. In: James, A.W., Walker, M.A. \& Weber, (ed). Proc. Rootstock Seminar: A worldwide perspective, June 1992, Reno, Nevada. p. 84.

Anonymous, 2006. Annual Report. National Research Centre for Grapes, Pune, India.

Arnous, A., Makris, D.P. \& Kefalas, P., 2001. Effect of principle polyphenolic composition in relation to antioxidant characteristics of aged red wines. J. Agric. Food Chem. 49, 5736-5742.

Asensio, M.L., Valdes, E. \& Cabello, F., 2002. Characterization of some Spanish white grapevine cultivars by morphology and amino acid analysis. Scientia Horticulturae 93, 289-299.

Bonilla, E.P., Akoh, C.C., Selappan, S. \& Krewer, G., 2003. Phenolic content and antioxidant capacity of Muscadine grapes. J. Agric. Food Chem. 51, 5497-5503.

Brown, C.S., Young, E. \& Pharr, D.M., 1985. Rootstock and scion effect on carbon partitioning in apple leaves. J. Am. Soc. Hort. Sci. 110, 696-701.

Carver, B.F., Burton, J.W. \& Wilson, R.F., 1987. Graft transmissible influence on fatty acid composition in soybean seeds. Crop Science 27, 53-56.

Dai, G.H., Andary, C., Cosson Mondolot, L. \& Boublas, D., 1994. Polyphenols and resistance of grape vines to downy mildew. Acta Horticulturae 381, 763-766.
Dzhambazova, T., Hvarleva, T., Hadjinicoli, A., Tsvetkov, I., Atanassov, A. \& Atanassov, I., 2007. Characterization of grapevine rootstocks using microsatellite markers. Biotechnol. and Biotechnol. 21, 58-62.

Hirata, Y., Yagishita, N., Ledoux, M., Thirty, M. \& Diels, L., 1986. Graft induces change in bell pepper and eggplant. Proc. 4th EUCARPIA Meeting on Genetics and Breeding in Capsicum and Egg Plant, Zaragoza, Spain. pp. 19-23.

Ju, Z.Y. \& Howard, L.R., 2003. Effect of solvent and temperature on pressurized liquid extraction of anthocyanin and total phenolics from dried red grape skin. J. Agric. Food Chem. 51, 5207-5213

Kim, M., Canio, W. \& Sinha, N., 2001. Developmental changes due to long distance movement of homebox fusion transcript in tomato. Science 293, 287-289.

Kim, D., Chun, O.K., Kim, Y.J., Moon, H. \& Lee, C.Y., 2003. Quantification of polyphenols and their antioxidants capacity in fresh plums. J. Agric. Food Chem. $51,6509-6515$

Kliewer, W.M., 1969. Free amino acids and other nitrogen substances of table grape varieties. J. Food Sci. 34, 274-278.

Krishankumar, R., Asokan, M.P. \& Sethuraj, M.R., 1992. Polymorphic isozyme expression caused by stock scion interaction in Hevea brasiliensis clone RRII 105. Indian J. Nat. Rubber Res. 5, 161-171.

Mazza, G., 1999. Anthocyanins in grape and grape products. Critical Reviews in Food Sci. Nutr. 35, 341-371.

Mazhan, H., Basha, S.M. \& Lu, J., 2002. Variation in berry protein composition of Muscadine cultivars. Am. J. Enol. Vitic. 53, 87-91.

Mochioka, R., Oder, Y. \& Tsu Bakimota, M., 2002. Relation between the rooting difficulty of cuttings and contents of phenolic compounds in shoots of Japanese wild grape Vitis kiusiana Momiyama. J. ASEV Japan 13, 2-8.

Nanda, K.K., 1979. Some studies on physiology of adventitious root formation. Abstr. No. 45. Int. Cashew Symp., March 1979, Cochin.

Ohta, Y. \& Choung, P.V., 1975. Hereditary changes in Capsicum annum L. 1 induced by ordinary grafting. Euphytica 24, 608-614.

Park, H. \& Cha, H., 2003. Flavonoids from leaves and exocarps of the grape kyoho. Korean J. Biol. Sci. 7, 327-330.

Ramteke, S.D. \& Karibasappa, G.S., 2005. Screening of grape genotypes for drought tolerance. Indian J. Agric. Sci. 75, 355-357.

Rosa, M.R., Juan, M.R. \& Romero, L., 2003. Role of grafting in horticultural plants under stress conditions. Food, Agriculture \& Environment 1, 70-74.

Sadhu, M.K. \& Bose, S., 1982. Proc. 21st Int. Hort. Cong., Hamburg. p. 1379.

Satisha, J., Prakash, G.S \& Venugopalan, R., 2006. Statistical modeling of water use efficiency with physiobiochemical parameters of grape rootstocks, genotypes and budded grapevines under soil moisture stress conditions. Turkish J. Agriculture and Forestry 30, 261-271.

Satisha, J. \& Prakash, G.S., 2006. The influence of water and gas exchange parameters on grafted grapevines under conditions of moisture stress. S. Afr. J. Enol. Vitic. 27, 40-45.

Sauer, 1972. Rootstock trials for Sultana grapes on light textured soils. Aust. J. Exptl. Agric. 12, 107-111.

Singleton, V.L. \& Rossi, J.A., 1965. Colorimetry of total phenolics with phosphomolybdic-phosphotungstic acid reagent. Am. J. Enol. Vitic. 16, 144-158.

Sobhana, P., 1998. Physiology of rooting and stock scion interaction in Hevea. Dissertation, Kerala University, India

Sobhana, P., Thomsa, M., Krishnakumar, R. \& Jacob, J., 2000. Can there be possible genetic conflict between genetically divergent rootstocks and scions in bud grafted plants? National Symposium on Recent Trends in Plant Science Research, University of Kerala, Trivandrum, India.

Spiegel, P., 1954. Auxins and inhibitors in canes of Vitis. Bul. Res. Coun. Israel 4, 176-183.

Sturve, D.K., 1981. The relation between carbohydrates, nitrogen and rooting of stem cuttings. The Plant Propagator 27, 6-7. 